\title{
Pathogenic microorganisms survival in ambrosia
}

\section{Sobrevivência de micro-organismos patogênicos em ambrosia}

\author{
Cláudio Dias Timm ${ }^{1 *}$; Daiani Teixeira Silva²; \\ Priscila Alves Dias ${ }^{3}$; Rita de Cássia Santos Conceição ${ }^{4}$
}

\begin{abstract}
Ambrosia is a kind of dulce de leche homemade with milk, eggs and sugar. It is usually sold in free markets and it is largely consumed in South America. Food contamination by pathogenic microorganisms can occur during the food processing, in distribution centers, in retail markets or in the consumer's homes. The aim of this study was to evaluate the survival in ambrosia of main pathogenic microorganisms eventually transmitted by dairy products. Ambrosia fractions were experimentally contaminated with Salmonella enterica subsp. enterica serotype Typhimurium, Escherichia coli O157:H7, Listeria monocytogenes and Staphylococcus aureus. Analysis to evaluate the microorganisms' viability were made after storage for 0, 1, 2, 3, 5, 10, 20 and 30 days. Salmonella and L. monocytogenes were recovered from all samples during the 30 days of study. E. coli $\mathrm{O} 157: \mathrm{H} 7$ was isolated until the tenth day and $S$. aureus until the third day. It was demonstrated that important pathogenic microorganisms are able to survive up to 30 days in ambrosia, which makes this product a potential carrier of food-borne diseases. This work is the first study about the possibility of ambrosia transmitting relevant public-health danger pathogenic microorganisms.

Key words: Ambrosia, dulce de leche, Salmonella, Listeria monocytogenes, Escherichia coli O157:H7, Staphylococcus aureus
\end{abstract}

\section{Resumo}

Ambrosia é um tipo de doce de leite preparado artesanalmente com leite, ovos e açúcar, comumente comercializado em feiras livres e muito consumido na América do Sul. A contaminação de alimentos por microrganismos patogênicos pode ocorrer durante as etapas de processamento, nos centros de distribuição, no mercado varejista ou na casa do consumidor. $\mathrm{O}$ trabalho teve como objetivo avaliar a sobrevivência em ambrosia dos principais microrganismos patogênicos eventualmente transmitidos por leite e derivados. Alíquotas de ambrosia foram experimentalmente contaminadas com Salmonella enterica subsp. enterica sorotipo Typhimurium, Escherichia coli $\mathrm{O} 157: \mathrm{H} 7$, Listeria monocytogenes e Staphylococcus aureus. Foram realizadas pesquisas dos microrganismos inoculados após 0, 1, 2, 3, 5, 10,20 e 30 dias de estocagem. Salmonella e L. monocytogenes foram recuperadas de todas as amostras durante os 30 dias de estudo. E. coli $\mathrm{O} 157: \mathrm{H} 7$ foi isolada até o $10^{\circ}$ dia e $S$. aureus foi recuperado até o terceiro dia de estocagem. Foi demonstrado que microrganismos patogênicos importantes em saúde pública são capazes de sobreviver por até 30 dias em ambrosia, o que faz deste doce um potencial veículo de doenças transmitidas por alimentos. O presente trabalho é o primeiro estudo sobre a possibilidade da ambrosia veicular microrganismos importantes em saúde pública.

Palavras-chave: Ambrosia, doce de leite, Salmonella, Listeria monocytogenes, Escherichia coli O157:H7, Staphylococcus aureus

\footnotetext{
${ }^{1}$ Prof. Associado de Inspeção de Produtos de Origem Animal, Universidade Federal de Pelotas, UFPel, Pelotas, RS. Brasil. E-mail: timm@ufpel.tche.br

${ }^{2}$ Discente de Doutorado, London School of Hygiene \& Tropical Medicine, Londres, Inglaterra. E-mail: daiani.ts@gmail.com

${ }^{3}$ Discente de Doutorado, UFPel, Pelotas, RS, Brasil. E-mail: dias.alvespri@gmail.com

${ }^{4}$ Prof ${ }^{a}$ Ajunta de Inspeção de Produtos de Origem Animal, UFPel, Pelotas, RS, Brasil. E-mail: ritac@ufpel.edu.br

* Author for correspondence
} 
Dulce de leche is a product obtained from the concentration and heating of milk with the addition of sucrose, developing a characteristic colour, texture and taste due to non-enzymatic browning reactions (HOUGH et al., 1991). This food is largely consumed in South America, especially in Brazil, Uruguay and Argentina, however there have not been much study about it. The ambrosia is a very popular kind of dulce de leche homemade with milk, eggs and sugar, usually sold in free markets.

Food contamination by pathogenic microorganisms is a potential hazard to people's health. Food can be contaminated by inadequate practices on the farm, during the manufacturing process, in the distribution centres, in the retail markets or in the consumers' homes. According to Timm et al. (2007) the possibility of dulce de leche carrying pathogenic bacteria cannot be excluded, in spite of its low water activity due to the high concentration of carbohydrates. The risk of ambrosia contamination is increased by homemade manufacture, many times under improper manipulation and environment exposition. There are few papers on dulce de leche in scientific bibliography. Most studies were developed in Argentina or Brazil and focus on the manufacturing process or the physical and chemical characteristics of the product.

The aim of this work was to evaluate the survival of the pathogenic microorganisms Salmonella enterica subsp. enterica serotype Typhimurium, $L$. monocytogenes, E. coli $\mathrm{O} 157: \mathrm{H} 7$ and $S$. aureus in ambrosia.

Salmonella enterica subsp. enterica serotype Typhimurium LIPOA 2046, which have been isolated from dulce de leche (TIMM et al., 2007), Escherichia coli O157:H7 ATCC 43895 resistant to nalidixic acid, Listeria monocytogenes LIPOA 3002 and Staphylococcus aureus LIPOA 4001, which have been isolated from sausage and cheese, respectively, were used. To induce resistance to nalidixic acid, the E. coli $\mathrm{O} 157: \mathrm{H} 7$ strain was successively cultured in Plate Count Agar (PCA, Acumedia, Michigan, USA) containing increasing concentrations of nalidixic acid until it grew in PCA with $100 \mu \mathrm{g}$ nalidixic acid per $\mathrm{mL}$ medium. The isolates were kept at $-70^{\circ} \mathrm{C}$ in Brain Heart Infusion (BHI, Acumedia) cultures mixed with an equal volume of glycerol at $80 \%$ in phosphate-buffered saline (PBS 0.01 M, pH 7.4) and recovered when necessary.

The strains were recovered by culture in BHI at $37^{\circ} \mathrm{C}$ for about twenty hours and grown until stationary phase. Inocula with about $10^{4}$ bacterial cells per $\mathrm{mL}$ were prepared from serial dilutions of the cultures in order to obtain final concentrations of about $10^{2}$ bacterial cells per $\mathrm{g}$, after ambrosia experimental contamination.

The ambrosia used for experimental contamination with pathogenic microorganisms was prepared from standardised milk containing 3\% milk fat. Twelve chicken eggs (yolk and albumen) and $500 \mathrm{~g}$ refined sugar was added to each liter of milk. The ingredients were homogenized and kept at $100-105^{\circ} \mathrm{C}$, without stirring, in an open pan on low fire for two hours.

Twenty-five gram ambrosia fractions were packed in sterile plastic bags, experimentally contaminated with $0.25 \mathrm{~mL}$ inoculum, homogenized and kept at a temperature between 15 and $20^{\circ} \mathrm{C}$. Analysis to evaluate the microorganisms' viability were made after storage for 0, 1, 2, 3, 5, 10, 20 and 30 days. Salmonella and L. monocytogenes recovery followed U.S. Food and Drug Administration (FDA) recommendations (ANDREWS; JACOBSON; HAMMACK, 2011; HITCHINS; JINNEMAN, 2003). To recover E. coli O157:H7, $225 \mathrm{~mL}$ Buffered Peptone Water (BPW, Acumedia) was added to the experimentally contaminated ambrosia and incubated at $37^{\circ} \mathrm{C}$ for 24 hours. Then $1 \mathrm{~mL}$ was transferred to $9 \mathrm{~mL}$ MacConkey broth (Difco, Maryland, USA) and incubated for 24 hours at $37^{\circ} \mathrm{C}$. From this culture, streaking on MacConkey agar (Difco) containing $100 \mu \mathrm{g}$ nalidixic acid per $\mathrm{mL}$ 
medium was performed and it was then incubated for 24 hours at $37^{\circ} \mathrm{C}$. To recover Staphylococcus aureus, each ambrosia contaminated fraction was incubated at $37^{\circ} \mathrm{C}$ for 24 hours in $225 \mathrm{~mL}$ Trypticase Soy Broth (TSB, Acumedia) containing 1\% (w/v) sodium pyruvate and $10 \%(\mathrm{w} / \mathrm{v})$ sodium chloride. Afterwards, streaking on Baird-Parker agar (Acumedia) was carried out from the culture and the plates were incubated for 24 hours at $37^{\circ} \mathrm{C}$ to obtain colony isolation and identification according to FDA recommendations (BENNETT; LANCETTE, 2001). Twenty-five grams of non- experimentally contaminated ambrosia was tested to check the presence of the studied microorganism species and serotypes for negative control. The experiment was performed in triplicate.

Salmonella and L. monocytogenes were recovered from all aliquots analysed. E. coli O157:H7 was recovered until the $10^{\text {th }}$ day after the experimental contamination and $S$. aureus until the $3^{\text {th }}$ day of storage. No microorganisms of the species and serotypes studied were recovered from the negative controls.

Ambrosia aliquots were experimentally contaminated with the main pathogenic microorganisms eventually transmitted by milk and dairy products. Although largely consumed, there are not reports about the role of this food in the food-borne diseases epidemiology. To our knowledge, the present paper is the first study about the putative transmission of relevant public-health hazardous microorganisms in ambrosia.

There are not reports about studies on microbiological evaluation and the hygienicsanitary quality of ambrosia. Even works about other kinds of dulce de leche were rare. The main study was made by Hentges et al. (2010) using pasty dulce de leche experimentally contaminated with pathogenic microorganisms. This researchers recovered Salmonella, E. coli, S. aureus and $L$. monocytogenes from dulce de leche experimentally contaminated at $10^{3}$ bacterial cells per $\mathrm{g}$ after storage for 30 days. Nevertheles, at $10^{1}$ bacterial cells per g concentration, E. coli and $S$. aureus did not survive beyond the $5^{\text {th }}$ and $10^{\text {th }}$ day, respectively. Our results are very similar to theirs, suggesting that the environment provided by pasty dulce de leche and ambrosia is not very distinct in regard to microorganisms survival.

Salmonella is one of the most common pathogens involved in food toxinfection outbreaks, and dairy products are important Salmonella carriers (CDC, 2011). On the other hand, L. monocytogenes occurrence in dairy products has been reported especially in cheese (BORGES et al., 2003; PARK et al., 2002; RULDOLF; SCHERER, 2001). The infectious dose of Salmonella Typhimurium may be lower than 10 bacterial cells (D'AOUST; MAURER; BAILEY, 2001), and Inoue et al. (2000) consider food with a L. monocytogenes concentration higher than $100 \mathrm{CFU} / \mathrm{g}$ as high risk food. Thus, the very presence of these pathogens in food is enough to raise concern on food safety. This fact, together with the survival ability of Salmonella and L. monocytogenes in this food, makes the ambrosia a product to be considered in the foodborne salmonellosis and listeriosis occurrence.

The Salmonella Typhimurium strain used in this work was isolated from dulce de leche in previous study (TIMM et al., 2007), therefore it is possible that the microorganism has adapted to the environment provided by this food. According to D'Aoust, Maurer e Bailey (2001), Salmonella is able to survive for long periods in food with high lipid concentrations, which protect the pathogen from unfavorable factors found in some foods. It is possible that the lipids of the whole milk and eggs used to prepare the ambrosia have contributed to the Salmonella survival during the 30 days of storage. Timm et al. (2007) consider that the common practice of opening the doce de leite containers in retail markets to sell in little portions increase the hazard of contamination and transmission of undesirable microorganisms to consumers. This circumstance may also occur because the handmade 
conditions of the preparation and packing of the ambrosia.

E. coli $\mathrm{O} 157: \mathrm{H} 7$ occurrence in food, as well as that of Salmonella and L. monocytogenes, is unacceptable. E. coli O157:H7 have been associated to several outbreaks of food-borne diseases and the dairy products have been reported as carriers for these bacteria (HUSSEIN; SAKUMA, 2005). The results obtained shows that this pathogen has limited ability to survive in the environment provided by ambrosia. However, survival up to 10 days can be dangerous, considering the severity of some clinical cases caused by E. coli $\mathrm{O} 157: \mathrm{H} 7$ and the very low infective dose to susceptible groups of 10 to 100 bacterial cells or even lower (ARMSTRONG; HOLLINGSWORTH; MORRIS, 1996).

$S$. aureus is very spread in the nature, and it is one of the more common agents of food intoxication outbreaks (BALABAN; RASOOLY, 2000). The microorganism is found in the nasal fossae and on the skin of $50 \%$ of healthy people. Food industry workers were usually implicated in the intoxication outbreaks, but equipment and environment also may be sources of contamination by $S$. aureus. The intoxication dose of enterotoxin is less than 1.0 microgram. This toxin level is reached when $S$. aureus populations exceed $10^{5}$ organisms/g in food (HAIT, 2012). Considering that the microorganism was only recovered from the experimentally contaminated samples up to three days after inoculation, it seems that even populations larger than those used in this study do not increase but may eventually decrease in the ambrosia environment. This, together with the bacterial concentration needed to produce enough enterotoxin to cause food poisoning in humans, suggests that ambrosia is not such a high hazard to consumers regarding foodborne $S$. aureus.

The simple fact of a food to be homemade produced does not mean that it does not have hygienic-sanitary quality to be a safe food to human consumption. However, when the products are not surveyed by official agencies, there are not guarantee of standardization of the hygiene processes nether inspection of the good manufacturing practices, which increase the hazards of food contamination and transmission of pathogenic microorganisms to humans.

In this study, it was demonstrated that relevant public-health danger pathogenic microorganisms were able to survive up to 30 days in ambrosia, which makes this product a potential carrier of foodborne diseases. The results are an alert regarding the adoption of appropriate hygienic-sanitary proceedings during the production, handling and packing of the ambrosia and the attention by the official agency of food inspection to homemade ambrosia.

\section{References}

ANDREWS, W. H.; JACOBSON, A.; HAMMACK, T. Salmonella. Bacteriological analytical manual. Chapter 5. Silver Spring: FDA, 2011. Available at: <http://www. fda.gov/Food/ScienceResearch/LaboratoryMethods/ BacteriologicalAnalyticalManualBAM/ucm070149. htm >. Accessed at: 20 aug 2012.

ARMSTRONG, G. L.; HOLLINGSWORTH, J.; MORRIS, J. G. Emerging foodborne pathogens: Escherichia coli $\mathrm{O} 157: \mathrm{H} 7$ as a model of entry of a new pathogen into the food supply of the developed world. Epidemiologic Review, Oxford, v. 18, n. 1, p. 29-51, 1996.

BALABAN, N.; RASOOLY, A. Staphylococcal enterotoxins (review). International Journal of Food Microbiology, Turino, v. 61, n. 1, p. 1-10, 2000.

BENNETT, R. W.; LANCETTE, G. A. Staphylococcus aureus. Bacteriological analytical manual. Chapter 12. Silver Spring: FDA. 2001. Available at: <http://www. fda.gov/Food/ScienceResearch/LaboratoryMethods/ BacteriologicalAnalyticalManualBAM/ucm071429. htm>. Accessed at: 20 aug. 2012.

BORGES, M. F.; FEITOSA, T.; NASSU, R. T.; MUNIZ, C. R.; AZEVEDO, E. H. F.; FIGUEIREDO, E. A. T. Microrganismos patogênicos e indicadores em queijo de coalho produzido no estado do Ceará, Brasil. Boletim do CEPPA, Curitiba, v. 21, n. 1, p. 31-40, 2003. 
CENTERS FOR DISEASE CONTROL AND PREVENTION - CDC. Salmonella. 2011. Available at: $<$ http://www.cdc.gov/salmonella $>$. Accessed at: 20 aug. 2012.

D'AOUST, J.; MAURER, J.; BAILEY, J. S. Salmonella species. In: DOYLE, M. P.; BEUCHAT, L. R.; MONTVILLE, T. J. Food microbiology: fundamental and frontiers. 2. ed. Washington: ASM, 2001. p. 141-178.

HAIT, J. Staphylococcus aureus. In: LAMPEL, K. A.; AL-KHALDI, S.; CAHILL, S. M. (Ed.). Bad bug book - foodborne pathogenic microorganisms and natural toxins. 2. ed. Silver Spring: FDA, 2012. 262 p.

HENTGES, D.; SILVA, D. T.; DIAS, P. A.; CONCEIÇÃO, R. C. S.; ZONTA, M. N.; TIMM, C. D. Pathogenic microorganism survival in dulce de leche. Food Control, Guildford, v. 21, n. 9, p. 1291-1293, 2010.

HITCHINS, A. D.; JINNEMAN, K. Detection and enumeration of Listeria monocytogenes in foods. Bacteriological analytical manual. Chapter 10. Silver Spring: FDA, 2003. Available at: <http://www.fda. gov/Food/ScienceResearch/LaboratoryMethods/ BacteriologicalAnalyticalManualBAM/ucm071400. htm>. Accessed at: 20 aug. 2012.

HOUGH, G.; BUERA, M. P.; MARTINEZ, E.; RESNIK, $\mathrm{S}$. Effect of composition on non-enzymatic browning rate in dulce de leche-like systems. Anales de la Asociación Química Argentina, Buenos Aires, v. 79, n. 1, p. 31-40, 1991.
HUSSEIN, H. S.; SAKUMA, T. Prevalence of shiga toxin-producing Escherichia coli in dairy cattle and their products. Journal of Dairy Science, Madison, v. 88, n. 2, p. 450-465, 2005.

INOUE, S.; NAKAMA, A.; ARAI, Y.; KOKUBU, Y.; MARUYAMA, T.; SAITO, A.; YOSHIDA, T.; TERAO, M.; YAMAMOTO, S.; KUMAGAI, S. Prevalence and contamination levels of Listeria monocytogenes in retail foods in Japan. International Journal of Food Microbiology, Torino, v. 59, n. 1-2, p. 73-77, 2000.

PARK, S.; SPAHR, U.; JEMMI, T.; SALMAN, M. D. Risk factors for L. monocytogenes contamination of dairy products in Switzerland, 1990-1999. Preventive Veterinary Medicine, Colorado, v. 53, n. 1, p. 55-65, 2002.

RULDOLF, M.; SCHERER, S. High incidence of Listeria monocytogenes in European red smear cheese. International Journal of Food Microbiology, Torino, v. 63, n. 1-2, p. 91-98, 2001.

TIMM, C. D.; CONCEIÇÃO, R. C. S.; COELHO, F. J. O.; ROOS, T. B.; TEJADA, T. S.; QUEVEDO, P. S.; HENTGES, A.; BRASIL, N. D. A. Avaliação microbiológica de doce de leite pastoso. Revista do Instituto Adolfo Lutz, São Paulo, v. 66, n. 3, p. 275-277, 2007. 
